\title{
Alveolar fractal box dimension inversely correlates with mean linear intercept in mice with elastase-induced emphysema
}

This article was published in the following Dove Press journal:

International Journal of COPD

26 March 2012

Number of times this article has been viewed

\author{
Mary P Andersen' \\ A Read Parham' \\ J Clifford Waldrep ${ }^{1,2}$ \\ Wayland N McKenzie' \\ Rajiv Dhand ${ }^{1,2}$ \\ 'Division of Pulmonary, Critical \\ Care, and Environmental Medicine, \\ Department of Internal Medicine, \\ University of Missouri, ${ }^{2}$ Research \\ Services, Harry S Truman Memorial \\ VA Hospital, Columbia, MO, USA
}

Correspondence: Rajiv Dhand

Division of Pulmonary, Critical Care and Environmental Medicine, One Hospital

Drive, Columbia MO, USA 65212

Tel +I 5738847806

Fax +I 5738844892

Email dhandr@health.missouri.edu
Rationale: A widely applicable model of emphysema that allows efficient and sensitive quantification of injury is needed to compare potential therapies.

Objectives: To establish such a model, we studied the relationship between elastase dose and the severity of emphysema in female C57BL/6J mice. We compared alveolar fractal box dimension $\left(\mathrm{D}_{\mathrm{B}}\right)$, a new measure which is an assessment of the complexity of the tissue, with mean linear intercept $\left(\mathrm{L}_{\mathrm{m}}\right)$, which is commonly used to estimate airspace size, for sensitivity and efficiency of measurement.

Methods: Emphysema was induced in female C57BL/6J mice by administering increasing intratracheal doses of porcine pancreatic elastase (PPE). Changes in morphology and static lung compliance $\left(C_{L}\right)$ were examined 21 days later. Correlation of $D_{B}$ with $L_{m}$ was determined in histological sections of lungs exposed to PPE. The inverse relationship between $\mathrm{D}_{\mathrm{B}}$ and $\mathrm{L}_{\mathrm{m}}$ was supported by examining similar morphological sections from another experiment where the development of emphysema was studied 1 to 3 weeks after instillation of human neutrophil elastase (HNE).

Results: $\mathrm{L}_{\mathrm{m}}$ increased with PPE dose in a sigmoidal curve. $\mathrm{C}_{\mathrm{L}}$ increased after 80 or $120 \mathrm{U} / \mathrm{kg}$ body weight $(P<0.05)$, but not after $40 \mathrm{U} / \mathrm{kg}$, compared with the control. $\mathrm{D}_{\mathrm{B}}$ progressively declined from $1.66 \pm 0.002$ (standard error of the mean) in controls, to $1.47 \pm 0.006$ after $120 \mathrm{U} P P E / \mathrm{kg}(P<0.0001)$. After PPE or HNE instillation, $\mathrm{D}_{\mathrm{B}}$ was inversely related to $\mathrm{L}_{\mathrm{m}}$ ( $R=-0.95, P<0.0001$ and $R=-0.84, P=0.01$, respectively), with a more negative slope of the relationship using $\operatorname{HNE}(P<0.0001)$.

Conclusion: Intratracheal instillation of increasing doses of PPE yields a scale of progression from mild to severe emphysema. $D_{B}$ correlates inversely with $L_{m}$ after instillation of either PPE or HNE and yields a rapid, sensitive measure of emphysema after elastase instillation.

Keywords: chronic obstructive pulmonary disease, pulmonary emphysema, lung morphometry, lung compliance

\section{Introduction}

Development of new drugs for the treatment of emphysema is hindered by the time required for the development of the disease state and by the lack of a sensitive, efficient measure to quantify the severity of injury. Furthermore, without a standardized model, it is difficult to compare results across studies. The most common methods of inducing emphysema are intratracheal instillation of either porcine pancreatic elastase (PPE), or human neutrophilic elastase (HNE). ${ }^{1-3} \mathrm{~A}$ bolus of elastase instilled intratracheally into mice produces acute lung injury, alveolar destruction, and airspace enlargement that stabilizes within 21 days. $^{2}$ Previous studies of elastase-induced emphysema in mice 
have used males or females of various strains and ages, with variable susceptibility to injury., ${ }^{2,4}$ In an effort to identify a standardized therapeutic model, the C57BL/6J wild-type strain was chosen for study because it possesses intrinsically low levels of alpha-1-antitrypsin, because it is the parent strain of the pallid mutant, which has reduced secretion of alpha-1-antitrypsin from the liver, ${ }^{7}$ and because it is amenable to creation of transgenic derivatives. ${ }^{8}$ Only one other group of investigators has examined the relation of multiple doses of elastase to morphometry in $\mathrm{C} 57 \mathrm{BL} / 6 \mathrm{~J}$ mice. ${ }^{9}$ However, that study did not establish a general model of elastase-induced emphysema because the mice used by them varied in age from 6 to 10 weeks, ages that span the end of very active lung growth into much slower growth, ${ }^{10}$ where susceptibility to elastase changes considerably. ${ }^{11}$

The C57BL/6J strain has been characterized as "mildly susceptible" to cigarette smoke-induced emphysema. ${ }^{12,13}$ Serum antitrypsin levels in male C57BL/6J mice are about $70 \%$ of those in other wild-type murine strains. ${ }^{13}$ Female $\mathrm{C} 57 \mathrm{BL} / 6 \mathrm{~J}$ mice have about half the serum antitrypsin levels of males, ${ }^{13,14}$ and this probably explains why the amount of elastase required to produce emphysema is lower for females than for males.

Ideally, parameters used to evaluate the severity of emphysema should allow a high degree of discrimination. Mean linear intercept $\left(\mathrm{L}_{\mathrm{m}}\right)$ is the most common morphometric method to assess emphysema in animal models. ${ }^{15}$ Although the calculation of $\mathrm{L}_{\mathrm{m}}$ provides reliable measurements of emphysema, it is not a true measure of alveolar size. ${ }^{16}$ Measurement of $\mathrm{L}_{\mathrm{m}}$ is labor intensive, and requires subjective distinction between alveolar structures and surrounding tissue. ${ }^{17}$ Image analysis software is available for performing more rapid calculations of $\mathrm{L}_{\mathrm{m}}$, but is expensive, and still requires subjective interpretation of the tissue. Other morphometric measures of emphysema, such as internal surface area (ISA), alveolar surface area, and alveolar number, also depend on subjective interpretation, volume measurements, which can be highly variable, and either meticulous manual measurements or expensive software. Thus, a more efficient measure is desirable; one that is sensitive to subtle changes in emphysema. One possible approach is to compare fractal properties of the lungs.

Measures of fractal dimension have recently gained importance because of their discriminatory capabilities. A fractal is an object or function that has self-similarity over several orders of scale. ${ }^{18}$ The fractal dimension is a measure of complexity, and tends to be characteristic for a normal, healthy form or process. Furthermore, the fractal dimension may change significantly with disease. ${ }^{19,20}$ When fractal properties are measured by laying a series of boxes over an image of a structure, the measure is called a fractal box dimension, or $\mathrm{D}_{\mathrm{B}}$. It is the slope of the regression line for the $\log -\log$ plot of box size (or scale) $C$ and count $N$, where $N$ is the number of boxes that contain a part of the image, from a box counting scan. In nature, the log-log plot normally yields a slightly concave line, so by convention $\mathrm{D}_{\mathrm{B}}$ is the limit as scale approaches zero: $\mathrm{D}_{\mathrm{B}}=\lim _{C \rightarrow 0}\left[\ln N / \ln C^{-1}\right] \cdot{ }^{21}$ Rigaut and coworkers established that lung alveolar surfaces have fractal properties at the microscopic level. ${ }^{22}$ Karperien has developed a user-friendly Image J software plug-in, called FracLac, ${ }^{21}$ which makes it possible to get fast, reliable measurements of $\mathrm{D}_{\mathrm{B}}$ from two dimensional images.

We report that, in elastase-induced emphysema, $D_{B}$ is inversely correlated with $\mathrm{L}_{\mathrm{m}}$, regardless of the type of elastase used, and is rapidly determined using the same digital images for measurement of $\mathrm{L}_{\mathrm{m}}$.

\section{Materials and methods Reagents}

High-purity PPE was obtained from Elastin Products, Inc (Owensville, MO). Each mg of protein contained 137 units PPE activity, where one unit solubilizes $1 \mathrm{mg}$ of elastin-orcein substrate in 20 minutes at $\mathrm{pH} 8.8$ and a temperature of $37^{\circ} \mathrm{C}$. HNE was obtained from the same source, in a concentration of 850 units/mg, where $1 \mathrm{HNE}$ unit hydrolyzes 1 Nmole sucala-ala-ala-pNA/min at $\mathrm{pH} 7.5$ and a temperature of $25^{\circ} \mathrm{C}$. It must be noted that the activity of these two enzymes cannot be directly compared. Despite having a 40\% homology, and the same active site mechanism, they differ with regard to $\mathrm{pH}$ and temperature optima, hydrophobicity, and substrate preferences. ${ }^{23}$ Ketamine $\mathrm{HCl}$ and ace promazine maleate were obtained from USP Fort Dodge Animal Health (Fort Dodge, IA). Xylazine was obtained from Phoenix Scientific, Inc (St Joseph, MO), and isoflurane and 10\% buffered formalin acetate from Fisher Scientific (St Louis, MO).

\section{Mice}

Seven-week-old C57BL/6J female mice were obtained from Jackson Laboratories (Bar Harbor, ME). Mice were housed in the vivarium at the Harry S Truman Memorial VA Hospital (Columbia, MO) in standard hanging shoebox cages, in isolation from other mice. Food and water were supplied ad libitum. Room temperature was $72^{\circ} \mathrm{F}-76^{\circ} \mathrm{F}$, relative humidity was $40 \%-50 \%$, and the day/night cycle was set at 12 hours/12 hours. Mice were acclimatized for 1 week before elastase instillation. All animal treatment 
was in accordance with a protocol approved by the Harry S Truman VA Subcommittee for Animal Studies.

\section{Elastase instillation}

Elastase was administered when mice were 8 weeks old, the midpoint of the transition from rapid to near stationary growth for this strain. At this age, the lungs have completed their most rapid growth ${ }^{10}$ and retain a moderate susceptibility to elastase. In preparation for instillation, mice were anesthetized with 5\% isoflurane for induction, and then maintained at 3\%-5\% isoflurane, with oxygen set at $0.6 \mathrm{~L} / \mathrm{min}$. Once mice were sedated, a $20 \mu \mathrm{L}$ ketamine/xylazine cocktail containing $25 \mathrm{mg} / \mathrm{mL}$ ketamine $\mathrm{HCl}$, and $0.625 \mathrm{mg} / \mathrm{mL}$ xylazine was injected intraperitoneally to prevent laryngeal spasms. A 20-gauge catheter (Beckton Dickinson, Rutherford, NJ) was inserted into the trachea via the mouth, connected to a manometer (custom made), and placement verified by briefly observing the characteristic liquid displacement of tidal breathing. After disconnecting the manometer, a bolus of elastase was then delivered into the catheter using a micropipette with a fine tip. For recovery, animals were given oxygen for 1 minute, and then placed in a warm chamber enriched with oxygen until they recovered consciousness, usually within 5 minutes.

For the study of PPE dosage effects, mice were given 40 , 80 , or 120 units of PPE per kg of body weight (abbreviated $\mathrm{U} / \mathrm{kg}$ ) in $100 \mu \mathrm{L}$ of phosphate-buffered saline (PBS). This range of doses was found in preliminary experiments (data not shown) to be adequate to produce emphysema in our model. Each dosage group, consisting of eight to ten mice after instillation, was subdivided for morphometry and lung compliance measurements to eliminate the possibility that morphometric results might be affected by manipulations of the lungs during compliance measurements. Mice were sacrificed 21 days after instillation.

To compare the effects of HNE on the relationship between the fractal box dimension and mean linear intercept, female mice from the same source and of the same age and strain received $700 \mathrm{HNE} \mathrm{U/kg} \mathrm{body} \mathrm{weight.} \mathrm{We} \mathrm{selected} \mathrm{this}$ dose because, in preliminary experiments, it was shown to reliably produce emphysema within 21 days, while higher doses resulted in pulmonary hemorrhage. Mice were sacrificed 7, 14, or 21 days postinstillation. Controls in each study received $100 \mu \mathrm{L}$ PBS alone.

\section{Static lung compliance $\left(C_{L}\right)$}

Animals were sacrificed by overdosing with $200-300 \mu \mathrm{L}$ ketamine/xylazine/ace promazine maleate cocktail $(100: 10: 2 \mathrm{mg} / \mathrm{mL})$, administered intraperitoneally.
The body cavity was opened and an incision was made in the trachea. A 20-gauge catheter was inserted into the trachea and secured with suture.

Static lung compliance was measured with a $5 \mathrm{cc}$ syringe connected to the trachea via a 20 -gauge catheter and to a water manometer via a three-way stopcock. For inflation curves, $0.2 \mathrm{cc}$ of air was manually injected stepwise, up to a total of $3.0 \mathrm{cc}$. The resultant pressure from each incremental injection was read from the manometer approximately 1 second after the injection. Deflation was read by the same method, manually withdrawing $0.2 \mathrm{cc}$ at a time, until $3.0 \mathrm{cc}$ was withdrawn. Inflation and deflation curves were measured twice for each animal. Volume was plotted as a function of pressure. $C_{L}$ was determined by the average slope of each deflation curve at its midpoint.

\section{Morphometry}

For morphometric studies, animals were sacrificed as described above. Lungs were excised from the body cavity with heart and trachea attached and fixed in $10 \%$ neutral buffered formalin acetate at a pressure of $25 \mathrm{~cm}$ of $\mathrm{H}_{2} \mathrm{O}$ for 8 hours. Whole lungs were embedded in paraffin, sectioned and stained with hematoxylin and eosin. Three sagittal lung sections of $4 \mu \mathrm{m}$ thickness were taken from the middle of each lung, so that a portion of each lung lobe was included in each section. Each subsequent section was spaced $200 \mu \mathrm{m}$ from the previous section. Paraffin embedding, sectioning, slide preparation for light microscopy, and staining with hematoxylin and eosin was done by the University of Missouri Research Animal Diagnostic Laboratory.

\section{Mean linear intercept $\left(L_{m}\right)$}

$\mathrm{L}_{\mathrm{m}}$ was measured according to the method of Dunnill using blind scoring. ${ }^{15}$ Identifying information on each slide was temporarily masked with a coded label, until after $\mathrm{L}_{\mathrm{m}}$ measurements were completed. Typically, there were 25 fields of lung tissue on each microscope slide. The fields were digitally photographed and saved (in jpeg format). Twelve suitable fields were randomly chosen and counted; a total of 36 fields were counted per animal. Areas with large airways were not selected for counting. $\mathrm{L}_{\mathrm{m}}$ was derived by superimposing a grid over each image and counting the number of times the alveolar walls intercepted the grid lines. The equation

$$
\mathrm{L}_{\mathrm{m}}=(\mathrm{N})(\mathrm{L}) / \mathrm{m}
$$

where $\mathrm{N}=$ number of times the transverses were placed on the tissue, $\mathrm{L}=$ length of the transverses and $\mathrm{m}=$ the sum of all intercepts, gave $\mathrm{L}_{\mathrm{m}}$. Because the $10 \%$ formalin fixation 
and paraffin embedding of mouse lungs has only a small effect on linear dimension, ${ }^{24}$ a correction factor was not applied to $\mathrm{L}_{\mathrm{m}}$.

\section{Alveolar box counting fractal dimension $\left(D_{B}\right)$}

$\mathrm{D}_{\mathrm{B}}$ of the alveolar walls was measured using the FracLac plugin, $\mathrm{v} 2.5$, for Image J. ${ }^{21}$ The images used for the measurement of $\mathrm{L}_{\mathrm{m}}$ were autocorrected for brightness and contrast using Microsoft Office Picture Manager (within Microsoft Office 2007; Microsoft, Redmond, WA), converted to grayscale, and exported to the tagged image file format. They were then imported into Image $\mathrm{J}$ in stacks, set to binary and unstacked, and saved in a new folder. FracLac was set for standard box count of binary images, using default parameters for grid calibers, and with added options for scanning, data processing, and graphics unchecked. Results were saved automatically. Accuracy was verified by scanning images of known fractal dimension. Six standard images scanned by this method tested within $\pm 1 \%$ of their known values. The binary images were scanned as a group. The correlation coefficient for each image scan, a test of the linear regression, was $\geq 0.995$ and indicates that the measured parameters are truly fractal. ${ }^{25}$

\section{Statistical analysis}

The mean and standard error were calculated for each outcome measure for different levels of elastase. A $P$ value of $<0.05$ was considered statistically significant. One-way analysis of variance (ANOVA) was used to make comparisons between the outcomes of different groups (Table 1, Figure 2). The residual plot from the fitted ANOVA model shows no serious violation of the normal assumption for the error terms. For estimating the correlations between the alveolar fractal box dimension $\left(\mathrm{D}_{\mathrm{B}}\right)$ and the mean linear intercept $\left(\mathrm{L}_{\mathrm{m}}\right)$, Spearman's correlation coefficient was chosen over Pearson's correlation coefficient, due to the non-normal distribution of outcome measures. Simple regression models were used to estimate slopes in Figure 3A and B. The effects of the two different types of elastase upon the inverse relationship between $\mathrm{D}_{\mathrm{B}}$ and
$\mathrm{L}_{\mathrm{m}}$ were compared by an F-test of the regression coefficients. Data analysis was compiled with the Kaleidagraph graphing and analysis program (v 4.0; Synergy Software, Reading, PA) and verified using SAS (v 9.2; SAS Institute Inc, Cary, NC).

\section{Results}

\section{Morphology and morphometry}

Low-power magnification images showed that, compared with the airspaces of PBS-treated controls, the airspaces of animals that received PPE were larger (Figure 1). Mice that received $40 \mathrm{U} / \mathrm{kg}$ had slightly enlarged airspaces and there was progressively greater airspace enlargement with higher PPE doses.

$\mathrm{L}_{\mathrm{m}}$ increased with increasing doses of PPE $(R=0.98$, Figure 2$). \mathrm{L}_{\mathrm{m}}$ of all PPE groups differed significantly $(P<0.05)$ from that of the PBS controls. However, $\mathrm{L}_{\mathrm{m}}$ after $120 \mathrm{U} / \mathrm{kg}$ was not significantly greater than $\mathrm{L}_{\mathrm{m}}$ after $80 \mathrm{U} / \mathrm{kg}(P=0.11)$. Similar results were obtained when $\mathrm{L}_{\mathrm{m}}$ measurements were compared with those from successively deeper cuts, verifying the uniformity of distribution (data not shown).

$\mathrm{D}_{\mathrm{B}}$ decreased with increasing doses of elastase. However, $\mathrm{D}_{\mathrm{B}}$ did not differ between the groups receiving 80 and $120 \mathrm{U} / \mathrm{kg}$ (Table 1). There was an inverse linear relationship between $\mathrm{D}_{\mathrm{B}}$ and $\mathrm{L}_{\mathrm{m}}$ measurements ( $R=-0.94$, Figure $3 \mathrm{~A}$ ).

In this study, to determine the relation of $\mathrm{D}_{\mathrm{B}}$ to $\mathrm{L}_{\mathrm{m}}$ independently, we compared the effect of PPE dose on each of the two measures. $D_{B}$ was linearly related to elastase dose by the following equation: $\mathrm{D}_{\mathrm{B}}=1.68-0.00137 \mathrm{X}$ dose, with a correlation coefficient of -0.895 . Despite the sigmoid relationship of $\mathrm{L}_{\mathrm{m}}$ to elastase dose, there was still a correlation of 0.978 for a linear relationship, where $\mathrm{L}_{\mathrm{m}}=51.9+0.563 \mathrm{X}$ dose. Solving both equations yields $\mathrm{D}_{\mathrm{B}}=1.81-0.0024 \mathrm{X} \mathrm{L}_{\mathrm{m}}$. This is remarkably close to the experimentally observed equation of the line in Figure 3A: $\mathrm{D}_{\mathrm{B}}=1.83-0.0028 \mathrm{X} \mathrm{L}_{\mathrm{m}}$.

\section{Effect of HNE}

$\mathrm{D}_{\mathrm{B}}$ and $\mathrm{L}_{\mathrm{m}}$ were calculated from images of lungs of mice that were sacrificed 7,14 , and 21 days after instillation of HNE (Figure 3B). An inverse relationship between

Table I Effect of porcine pancreatic elastase dose on alveolar fractal box dimension $\left(D_{B}\right)$

\begin{tabular}{lllll}
\hline Dose (U/kg) & Mean $\mathbf{D}_{\mathbf{B}}$ & SEM & Images (N) & *P (compared to control) \\
\hline 0 & 1.66 & 0.0016 & 293 & - \\
40 & 1.58 & 0.0035 & 299 & $<0.0001$ \\
80 & 1.47 & 0.0052 & 372 & $<0.0001$ \\
120 & 1.47 & 0.0055 & 368 & $<0.0001$ \\
\hline
\end{tabular}

Notes: $* P<0.0001$ for all comparisons of pairs, except that $D_{B}$ values after instillation of 80 and $120 \mathrm{U} / \mathrm{kg}$ did not differ. $P=0.75, R=-0.996$. The $P$ value of the global test $=0.007$ from the fitted analysis of variance model.

Abbreviation: SEM, standard error of the mean. 

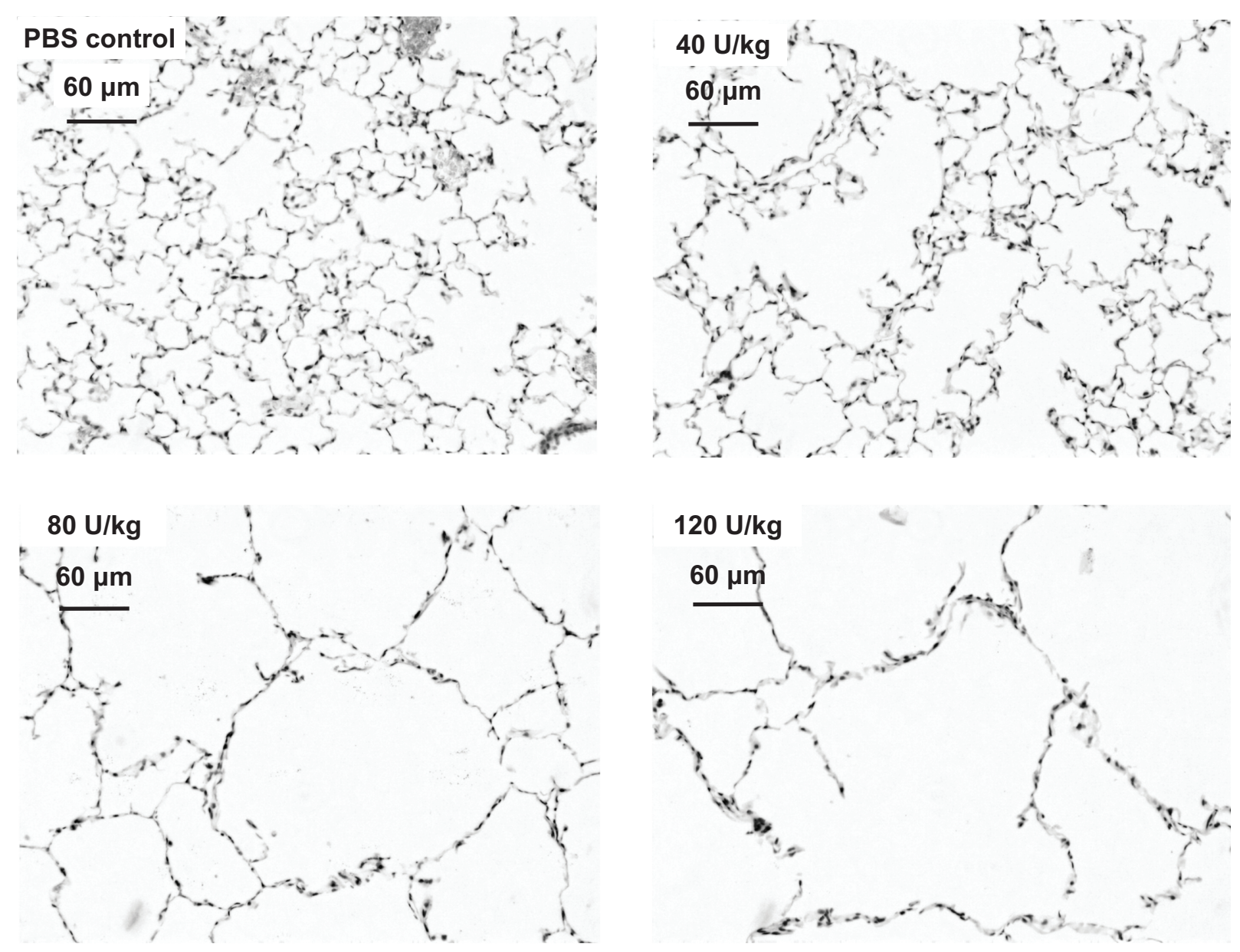

Figure I Photomicrographs of lungs 2 I days after elastase instillation, stained with hematoxylin and eosin (magnification 200x). Representative sections after instillation of phosphate-buffered saline (PBS) control, $40 \mathrm{U} / \mathrm{kg}$ body weight, $80 \mathrm{U} / \mathrm{kg}$, and $120 \mathrm{U} / \mathrm{kg}$ are shown.

Note: Scale bars represent $60 \mu \mathrm{m}$.

$\mathrm{D}_{\mathrm{B}}$ and $\mathrm{L}_{\mathrm{m}}$ was seen $(R=-0.83, P=0.01)$. The slopes of the linear relationships of $\mathrm{D}_{\mathrm{B}}$ and $\mathrm{L}_{\mathrm{m}}$ were shown to be different when compared using an F-test $(-0.0028$ for PPE and -0.0041 for HNE, respectively $[P<0.0001]$ ).

While $\mathrm{L}_{\mathrm{m}}$ increased over time after $\mathrm{HNE}$ was administered, $\mathrm{D}_{\mathrm{B}}$ decreased (Table 2). By 21 days after HNE, $\mathrm{D}_{\mathrm{B}}$ and $\mathrm{L}_{\mathrm{m}}$ differed significantly from those of saline-instilled controls $\left(P<0.0001\right.$ for $\mathrm{D}_{\mathrm{B}}$, and $P=0.05$ for $\left.\mathrm{L}_{\mathrm{m}}\right)$.

\section{Static lung compliance}

Figure 4 shows changes in static lung compliance 21 days after instillation of PPE. $\mathrm{C}_{\mathrm{L}}$ did not increase after instillation of $40 \mathrm{U} / \mathrm{kg}(P=0.25)$. However, after 80 or $120 \mathrm{U} / \mathrm{kg}$, $\mathrm{C}_{\mathrm{L}}$ was greater than the control values, and values obtained after $40 \mathrm{U} / \mathrm{kg}(P<0.001$ for each $)$.

\section{Discussion}

This study addressed the need for a more standardized and efficient means of comparing results in murine studies of emphysema. It characterized the dose-response to PPE in 8-week-old female C57BL/6J mice, and compared morphometric and functional parameters of measurement of alveolar damage to find the best means of distinguishing the degree of injury. Alveolar fractal box dimension $\left(D_{B}\right)$ was identified as a measure of alveolar lung damage, which is inversely related to $L_{m}$. This finding was confirmed in a separate study using HNE.

PPE affected the severity of emphysema as follows: $40 \mathrm{U} / \mathrm{kg}$ produced mild emphysema, where $C_{L}$ was unaffected, but changes in $\mathrm{L}_{\mathrm{m}}$, and $\mathrm{D}_{\mathrm{B}}$ were noted. $80 \mathrm{U} / \mathrm{kg}$ produced moderate emphysema, with progressively greater changes in $\mathrm{L}_{\mathrm{m}}$ and $\mathrm{D}_{\mathrm{B}} .120 \mathrm{U} / \mathrm{kg}$ produced the most severe degree of emphysema, with marked changes in all the measured parameters, but also resulted in some fatalities immediately after instillation, in less than $20 \%$ of the mice, mostly due to acute pulmonary hemorrhage. Together, these findings provide a scale of reference for the comparison of alveolar injury in this model. The relationship between $\mathrm{L}_{\mathrm{m}}$ and PPE 


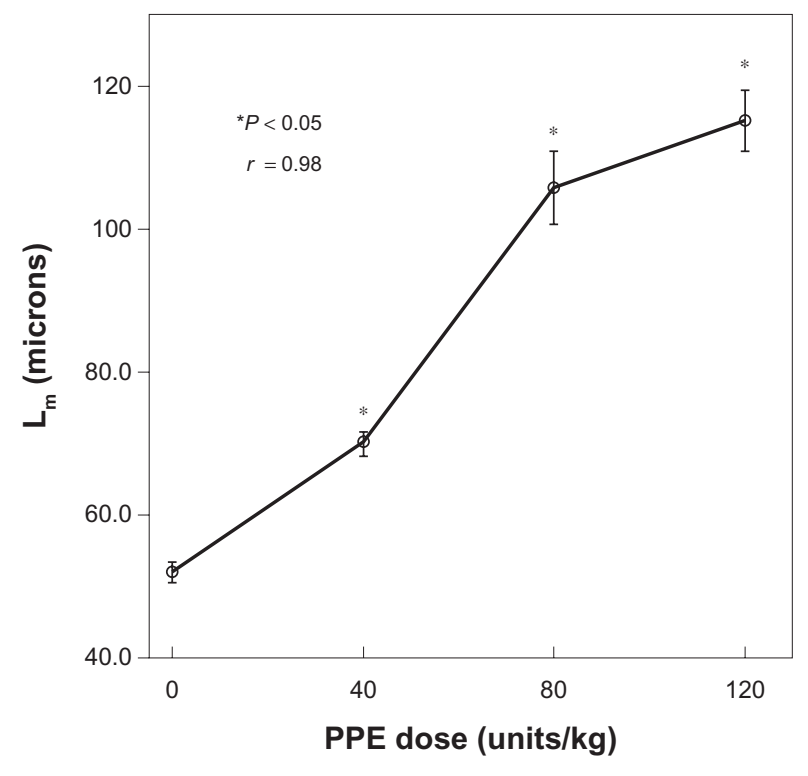

Figure 2 Relationship between the mean linear intercept $\left(L_{m}\right)$ and the dose of porcine pancreatic elastase (PPE). $L_{m}$ increased when the PPE dose increased. Notes: Error bars \pm standard error of the mean ( $N=4$ or 5 for each dose). *Significantly different from control by analysis of variance (ANOVA) $(P<0.05)$. All groups were significantly different by ANOVA, except $L_{m}$ of $80 \mathrm{U} / \mathrm{kg}$ was not different from an $L_{m}$ of $120 \mathrm{U} / \mathrm{kg}(P=0.1 \mathrm{I})$. Pearson's correlation, $R=0.98$. $P$ value of the global test $=0.00 \mathrm{I}$ from the fitted ANOVA model.

(Figure 2A) resembles a typical dose-response curve for a toxin, ${ }^{26}$ where the effective concentration required to achieve one half of the maximum effect $\left(\mathrm{EC}_{50}\right)$ is about $50 \mathrm{U} / \mathrm{kg}$.

$D_{B}$

$\mathrm{D}_{\mathrm{B}}$, a measure of the complexity of the alveolar surface, progressively declined with increasing doses of elastase, as airspace size $\mathrm{L}_{\mathrm{m}}$ increased. $\mathrm{D}_{B}$ is inversely correlated with $\mathrm{L}_{\mathrm{m}}$ regardless of the type of elastase used, but, with $\mathrm{HNE}$, each unit increase of $\mathrm{L}_{\mathrm{m}}$ was accompanied by a correspondingly greater decline in $\mathrm{D}_{\mathrm{B}}$ than with PPE. This may reflect differences in the action of the two enzymes upon lung structures, as well as differences in susceptibility to naturally occurring inhibitors present in the lung, such as alpha-1-antitrypsin and secretory leukocyte protease inhibitor. ${ }^{23,27}$

Only a few other investigators have attempted to measure lung damage by some type of fractal measure and their findings are not easily compared because each used different parameters to generate a fractal dimension. Among these, Witten et $\mathrm{al}^{28}$ found that the perimeter length of airspaces of COPD patients had a lower fractal dimension than did those of healthy individuals. Nagao et $\mathrm{al}^{29}$ reported increased fractal dimension of radioaerosol density probabilities in human emphysema, but these data were criticized for not measuring a fractal characteristic. ${ }^{30}$ In contrast, Sato et $\mathrm{al}^{25}$ examined fractal parameters of alveolar size distribution

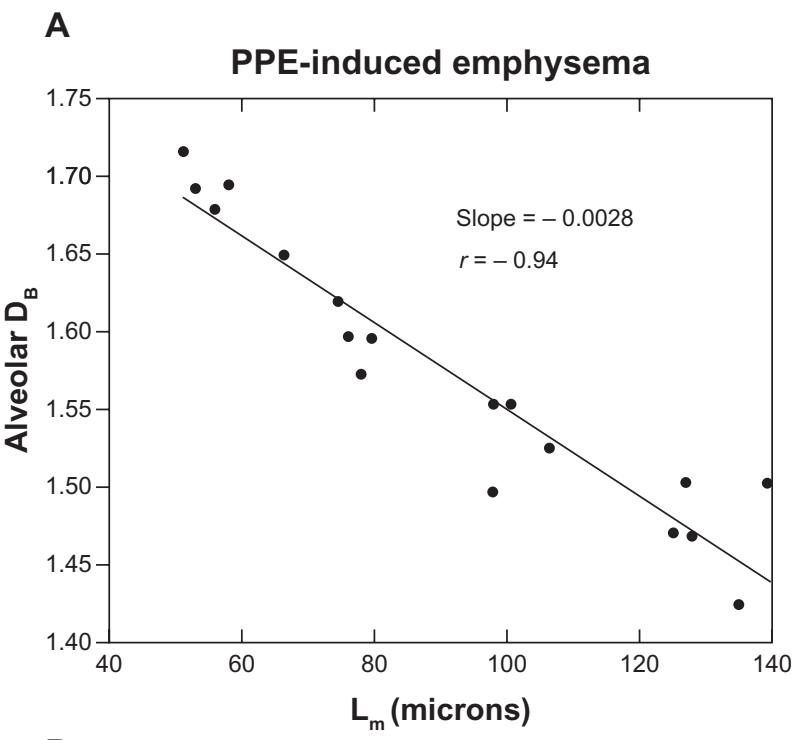

B

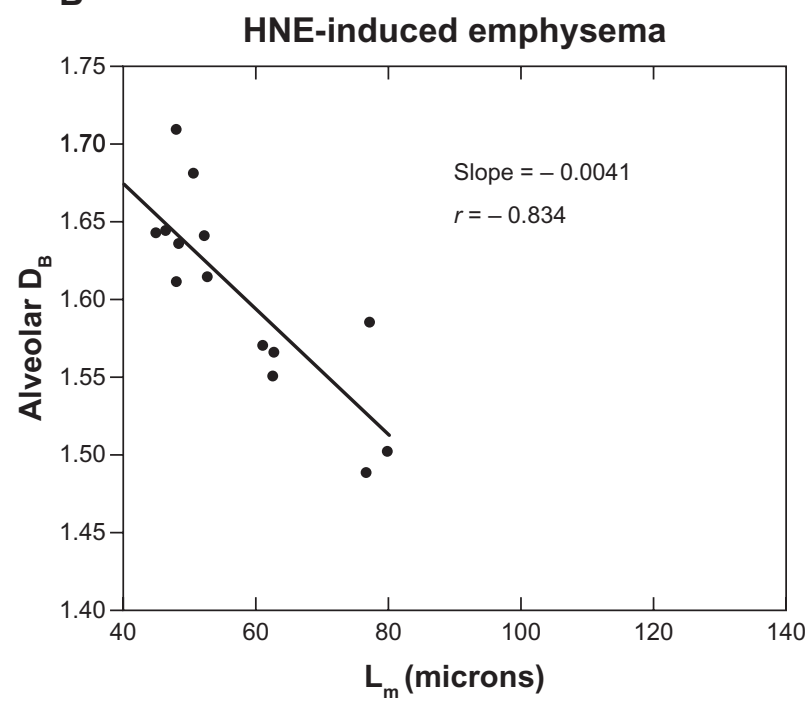

Figure 3 Relationship between alveolar fractal box dimension $\left(D_{B}\right)$ and mean linear intercept $\left(L_{m}\right)$. Each datum point is the mean $D_{B}$ and $L_{m}$ of one animal. (A) Porcine pancreatic elastase (PPE)-induced emphysema $(\mathrm{N}=18)$. Estimated Spearman's coefficient of correlation $R=-0.94, P<0.000 \mathrm{I}$. (B) human neutrophil elastase (HNE)-induced emphysema ( $N=14)$. Spearman's coefficient, $R=-0.834 . P=0.0001$. Notes: The slopes of the lines, -0.0028 and -0.0041 , respectively, are significantly different when compared by an F-test $(P<0.0001)$. The negative correlation coefficients indicate that as airspace size $L_{m}$ increases there is a corresponding decline in $D_{B}$, regardless of the type of elastase used to induce emphysema. The difference between the slopes of the lines indicates that HNE reduces $D_{B}$ more for each unit of increase in airspace size $L_{m}$ than does PPE.

and shape distribution in klotho mice, which spontaneously develop emphysema during aging. They found that those parameters are truly fractal and declined with the development of emphysema. Measures of fractal dimension can be applied to computed tomography (CT) scans of the human lung to examine the extent and localization of emphysema. Although such measures have been hampered by variability between scans, Keller et $\mathrm{al}^{31}$ have recently reported a technique to address this problem. The box counting method we 
Table 2 Effect of human neutrophil elastase on alveolar fractal box dimension $\left(D_{B}\right)$ and mean linear intercept $\left(L_{m}\right)$

\begin{tabular}{lllll}
\hline Time & Mean $D_{B}$ & SEM of $D_{B}$ & $L_{m}$ & SEM of $L_{m}$ \\
\hline Control $^{a}$ & 1.69 & 0.03 & 38.5 & 2.1 \\
7 & 1.62 & 0.020 & 51.3 & 15.2 \\
14 & 1.62 & 0.029 & 53.9 & 4.6 \\
21 & $1.57^{*}$ & 0.026 & $60.4^{*}$ & 7.0 \\
\hline
\end{tabular}

Notes: aSaline instilled controls were sacrificed 2 I days postinstillation; *significantly different than controls.

Abbreviation: SEM, standard error of the mean.

have used on alveolar surfaces is not equivalent to any of the other methods. We have shown that it is truly a fractal measure of alveolar surfaces and that it is inversely related to the $\mathrm{L}_{\mathrm{m}}$ in this emphysema model.

When HNE is used to induce emphysema in our model, the more negative slope of the relationship between $\mathrm{D}_{\mathrm{B}}$ and $\mathrm{L}_{\mathrm{m}}$, compared to that found with PPE, is due to a greater decline in $\mathrm{D}_{\mathrm{B}}$ for each unit of increase in $\mathrm{L}_{\mathrm{m}}$. The airspaces do not increase in size as much as with PPE, because the animals will die of hemorrhage at doses of HNE that increase $\mathrm{L}_{\mathrm{m}}$ above about $80 \mu \mathrm{m}$. However, at the same time, a change is occurring that affects $\mathrm{D}_{\mathrm{B}}$ relatively more than does PPE for the same change in $\mathrm{L}_{\mathrm{m}}$. The cause of death with either enzyme most frequently appears to be pulmonary hemorrhage, suggesting that pulmonary vascular tissues may be more readily damaged by HNE than by PPE and that the integrity of the vascular tissue may be more crucial to survival than airspace size. Again, it is important to stress that these two enzymes have less in common than suggested by calling

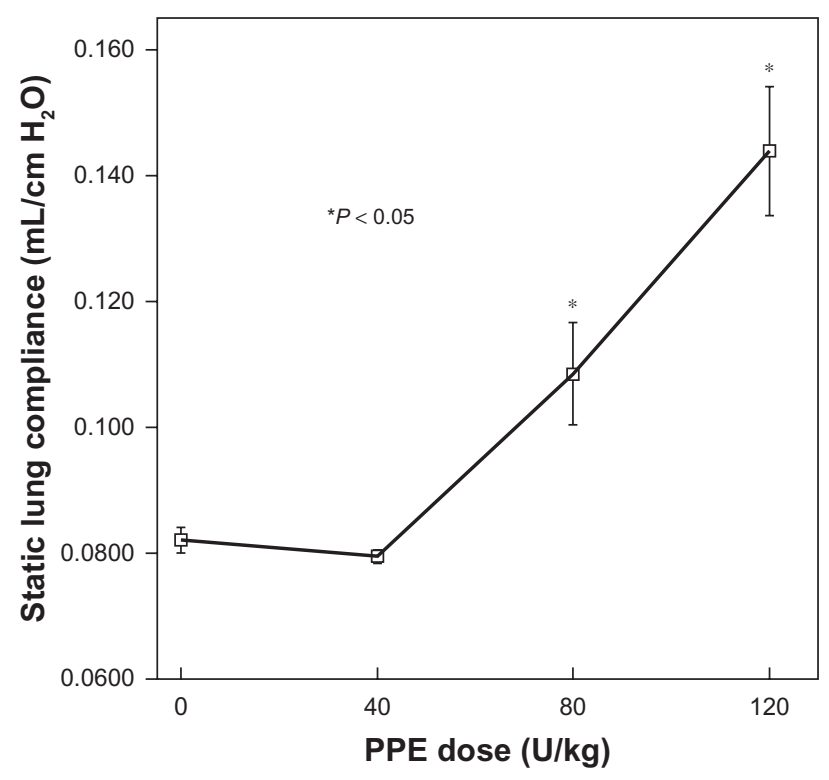

Figure 4 Relationship of static lung compliance $\left(C_{L}\right), 21$ days after porcine pancreatic elastase (PPE) instillation, to PPE dose.

Notes: Error bars \pm standard error of the mean $(\mathrm{N}=4$ or 5 for each dose). *Significant difference from control $(P<0.05)$. them both elastase; HNE is hydrophobic and more active against vascular tissues, whereas PPE is hydrophilic. Each acts upon other substrates besides elastin and PPE is less susceptible to elastase inhibitors normally found in the lung than is HNE. ${ }^{23,27}$

In our study, the $\mathrm{D}_{\mathrm{B}}$ of controls was close to 1.7 , a value that is commonly found for diffusion-limited processes, such as the growth of vasculature, ${ }^{18}$ whereas $D_{B}$ in elastaseexposed mice was reduced, regardless of the type of elastase used. The maximum tolerated dose of PPE, $120 \mathrm{U} / \mathrm{kg}$, roughly corresponds to a minimum $\mathrm{D}_{\mathrm{B}}$ of about 1.4 to 1.5 in this study. With HNE instillation, the maximal $\mathrm{L}_{\mathrm{m}}$ was only about half that obtained with PPE, while $\mathrm{D}_{\mathrm{B}}$ declined nearly as much as with PPE, resulting in a significantly steeper negative relationship between $D_{B}$ and $L_{m}$.

Since $D_{B}$ is measured by digital scanning, it may be calculated rapidly, and is limited primarily by available computer memory. In our study, FracLac scanned each binary image in seconds. The option to automatically save the results permitted the processing of more than 1200 images overnight without supervision. $\mathrm{D}_{\mathrm{B}}$ may prove to be a very useful measure for comparative studies of emphysema, especially in mild emphysema where changes in other parameters may be small or difficult to measure.

\section{Static lung compliance}

Static lung compliance measurements were relatively insensitive to the dose of PPE (Figure 4), compared with $\mathrm{L}_{\mathrm{m}}$ and $D_{B} . C_{L}$ increased only with the highest doses of PPE. Our results are similar to those of other investigators. Takubo and colleagues ${ }^{32}$ used a smoking model of emphysema to compare changes in the C57BL/6J strain with its pallid derivative. The wild-type strain developed mild emphysema but did not exhibit an increase in $\mathrm{C}_{\mathrm{L}}$, whereas the pallid derivative ${ }^{5}$ had significantly more emphysema and an increase in $\mathrm{C}_{\mathrm{L}}$. Similarly, Foronjy and coinvestigators ${ }^{33}$ found that transgenic mice that overproduce matrix metalloprotease-1 developed increased $\mathrm{L}_{\mathrm{m}}$, but not increased $\mathrm{C}_{\mathrm{L}}$ after 2 months. However, after 1 year, with further increase in $\mathrm{L}_{\mathrm{m}}, \mathrm{C}_{\mathrm{L}}$ also increased. Thus, a modest increase of airspace size, as measured by $\mathrm{L}_{\mathrm{m}}$, is not necessarily associated with increased $C_{L}$ in mice and changes in $C_{L}$, while functionally important, are not a sensitive measure of elastase-induced lung damage.

\section{Conclusion}

This study characterized a dose-dependent response to PPE injury in the mouse lung. $\mathrm{L}_{\mathrm{m}}$ showed a classical, 
sigmoid dose-response curve, with an $\mathrm{EC}_{50}$ corresponding to approximately $50 \mathrm{U} / \mathrm{kg}$ body weight for females of strain C57BL/6J. $D_{B}$ inversely corresponded to $\mathrm{L}_{\mathrm{m}}$ regardless of the type of elastase used, whereas $C_{L}$ was relatively unaffected by the lowest dose of PPE.

$\mathrm{D}_{\mathrm{B}}$ and $\mathrm{L}_{\mathrm{m}}$ are both sensitive measures of emphysema development after elastase instillation, able to discriminate between mild and more severe lung damage. $\mathrm{D}_{\mathrm{B}}$ provides rapid assessment of the severity of emphysema and may prove to be especially useful in comparing therapies for emphysema.

\section{Acknowledgments}

We thank Drs Youngju Pak and Richard Madsen for providing statistical guidance and Sharon S Morey for reviewing the manuscript (all University of Missouri, Columbia, MO).

\section{Disclosure}

J Clifford Waldrep is a senior investigator at the US Army Medical Research Institute of Infectious Diseases (USAMRIID), Frederick, MD. This research was supported by the Harry S. Truman VA Research Service and the Department of Internal Medicine, University of Missouri, Columbia, Missouri, USA. The authors declare no other conflicts of interest in this work.

\section{References}

1. Lucey EC, Goldstein RH, Breuer R, Rexer BN, Ong DE, Snider GL. Retinoic acid does not affect alveolar septation in adult FVB mice with elastase-induced emphysema. Respiration. 2003;70(2):200-205.

2. Lucey EC, Keane J, Kuang PP, Snider GL, Goldstein RH. Severity of elastase-induced emphysema is decreased in tumor necrosis factoralpha and interleukin-1beta receptor-deficient mice. Lab Invest. 2002; 82(1):79-85.

3. Snider GL, Lucey EC, Stone PJ. Animal models of emphysema. Am Rev Respir Dis. 1986;133(1):149-169.

4. Fujita M, Ye Q, Ouchi H, Nakashima N, Hamada N, Hagimoto N, et al. Retinoic acid fails to reverse emphysema in adult mouse models. Thorax. 2004;59(3):224-230.

5. Gardi C, Cavarra E, Calzoni P, et al. Neutrophil lysosomal dysfunctions in mutant $\mathrm{C} 57 \mathrm{BL} / 6 \mathrm{~J}$ mice: interstrain variations in content of lysosomal elastase, cathepsin G, and their inhibitors. Biochem J. 1994; 299:237-245.

6. Valentine R, Rucker RB, Chrisp CE, Fisher GL. Morphological and biochemical features of elastase-induced emphysema in strain A/J mice. Toxicol Appl Pharmacol. 1983;68(3):451-461.

7. White RA, Peters LL, Adkison LR, Korsgren C, Cohen CM, Lux SE. The murine pallid mutation is a platelet storage pool disease associated with the protein 4.2 (pallidin) gene. Nat Genet. 1992;2(1):80-83.

8. The Jackson Laboratory. C57BL/6J [datasheet on the Jax ${ }^{\circledR}$ Mice Database]. Bar Harbor, ME: The Jackson Laboratory, 2009. Available from: http:// jaxmice.jax.org/strain/000664.html. Accessed December 16, 2011.

9. Couillin I, Vasseur V, Charron S, et al. IL-1R1/MyD88 signaling is critical for elastase-induced lung inflammation and emphysema. J Immunol. 2009;183(12):8195-8202.
10. Kawakami M, Paul JL, Thurlbeck WM. The effect of age on lung structure in male BALB/cNNia inbred mice. Am J Anat. 1984;170(1): $1-21$.

11. Martorana PA, van Even P, Schaper J. The effect of lung growth on the evolution of elastase-induced emphysema in the hamster. Lung. 1982; 160(1):19-27.

12. Guerassimov A, Hoshino Y, Takubo Y, et al. The development of emphysema in cigarette smoke-exposed mice is strain dependent. Am J Respir Crit Care Med. 2004;170(9):974-980.

13. Minnich M, Kueppers F, James H. Alpha-1-antitrypsin from mouse serum: Isolation and characterization. Comp Biochem Physiol B. 1984; 78(2):413-419.

14. Yamamoto K, Sinohara H. Regulation by sex hormones of serum levels of contrapsin and alpha 1-antiprotease in the mouse. Biochem Biophys Acta. 1984;798(2):231-234.

15. Dunnill MS. Quantitative methods in the study of pulmonary pathology. Thorax. 1962;17:320-328.

16. Hsia CCW, Hyde DM, Ochs M, Weibel ER; the ATS/ERS Joint Task Force on the Quantitative Assessment of Lung Structure. An official research policy statement of the American Thoracic Society/European Respiratory Society: standards for quantitative assessment of lung structure. Am J Respir Crit Care Med. 2010;181(4):394-418.

17. Knudsen L, Weibel ER, Gundersen HJG, Weinstein FV, Ochs M. Assessment of air space size characteristics by intercept (chord) measurement: an accurate and efficient stereological approach. J Appl Physiol. 2010;108(2):412-421.

18. Masters BR. Fractal analysis of the vascular tree in the human retina. Annu Rev Biomed Eng. 2004;6(1):427-452.

19. Moal F, Chappard D, Wang J, et al. Fractal dimension can distinguish models and pharmacologic changes in liver fibrosis in rats. Hepatol. 2002;36(4):840-849.

20. Detection of architectural distortion in prior mammograms of intervalcancer cases with neural networks. Engineering in Medicine and Biology Society, 2009. EMBC 2009. Annual International Conference of the IEEE; September 3-6, 2009.

21. Karperien A. FracLac for Image J, version 2.5 [computer program]. 2007. Available from: http://rsb.info.nih.gov/ij/plugins/fraclac/fraclac. html. Accessed December 16, 2011.

22. Rigaut JP, Berggren P, Robertson B. Stereology, fractals and semifractals-the lung alveolar structure studied through a new model. Acta Stereol. 1987;6(1):63-67.

23. Bode W, Meyer E, Powers JC. Human leukocyte and porcine pancreatic elastase: $x$-ray crystal structures, mechanism, substrate specificity, and mechanism-based inhibitors. Biochemistry. 1989; 28(5):1951-1963.

24. Lum H, Mitzner W. Effects of $10 \%$ formalin fixation on fixed lung volume and lung tissue shrinkage. A comparison of eleven laboratory species. Am Rev Respir Dis. 1985;132(5):1078-1083.

25. Sato A, Hirai T, Imura A, et al. Morphological mechanism of the development of pulmonary emphysema in klotho mice. Proc Natl Acad. Sci U S A. 2007;104(7):2361-2365.

26. Meddings JB, Scott RB, Fick GH. Analysis and comparison of sigmoidal curves: application to dose-response data. Am J Physiol-Gastr L. 1989; 257(6):G982-G989.

27. Barrett AJ. Leukocyte elastase. In: Laszlo L, editor. Methods in Enzymology. London: Academic Press; 1981:581-588.

28. Witten ML, Tinajero JP, Sobonya RE, Lantz RC, Quan SF, Lemen RJ. Human alveolar fractal dimension in normal and chronic obstructive pulmonary disease subjects. Res Commun Mol Pathol Pharmacol. 1997; 98(2):221-230.

29. Nagao M, Murase K. Measurement of heterogeneous distribution on Technegas SPECT images by three-dimensional fractal analysis. Ann Nucl Med. 2002;16(6):369-376.

30. Chung HW, Nagao M. Fractal analysis of nuclear medicine images again: validity and interpretation of results from new analysis methods. J Nucl Med. 2003;44(2):316-317. 
31. Keller BM, Reeves AP, Henschke CI, Yankelevitz DF. Multivariate compensation of quantitative pulmonary emphysema metric variation from low-dose, whole-lung CT scans. Am J Roentgenol. 2011;197(3): W495-W502.

32. Takubo Y, Guerassimov A, Ghezzo H, et al. Alpha1-antitrypsin determines the pattern of emphysema and function in tobacco smokeexposed mice: parallels with human disease. Am J Resp Crit Care. 2002;166(12 Pt 1):1596-1603.
33. Foronjy RF, Mercer BA, Maxfield MW, Powell CA, D’Armiento J, Okada Y. Structural emphysema does not correlate with lung compliance: lessons from the mouse smoking model. Exp Lung Res. 2005;31(6):547-562.

International Journal of COPD

\section{Publish your work in this journal}

The International Journal of COPD is an international, peer-reviewed journal of therapeutics and pharmacology focusing on concise rapid reporting of clinical studies and reviews in COPD. Special focus is given to the pathophysiological processes underlying the disease, intervention programs, patient focused education, and self management protocols.

\section{Dovepress}

This journal is indexed on PubMed Central, MedLine and CAS. The manuscript management system is completely online and includes a very quick and fair peer-review system, which is all easy to use. Visit http://www.dovepress.com/testimonials.php to read real quotes from published authors.

Submit your manuscript here: http://www.dovepress.com/international-journal-of-copd-journal 